Dr. J. D. B. HARRISON, a former Deputy Minister of the

then federal Department of Forestry, and a past president of the

Canadian Society of Forest Engineers, reviews

\title{
Expanding Forestry Horizons
}

This book is a significant contribution to Canadian history. It tells how a dream of a nation-wide organization of professional foresters, shared by a few men in the face of public apathy and industrial indifference, led to the establishment of the Canadian Society of Forest Engineers and its successor, the Canadian Institute of Forestry.

In the main narrative, covering a period of sixty years, the author has relied heavily upon direct quotations from the sayings and writings of leading men, linked together by his own illuminating and sometimes pungent comments. Thus by means of a skilful and very fair selection of documentary evidence he has managed to convey a clear idea of both the substance and the flavour of the hopes and fears, agreements and differences, frustrations and accomplishments which have marked progress from the possibly naive idealism of the founders to the organized sophistication of today.

It is no mean story. For example, we note with astonishment how that gentle scholar, F. W. H. Jacombe, not only first proposed the formation of a national society of foresters but, following the first meeting of a small group in Montreal, sat up alone until two o'clock in the morning to draft its first constitution. That document has been subjected to endless scrutiny and amendment but its principles still stand.

The book is occasionally brightened by flashes of humour, one of which is found in the first annual financial statement of a newly established Section. From it we learn that section dues provided a revenue of $\$ 18.00$ of which $\$ 1.42$ was spent on stamps and a receipt book and $\$ 15.04$ went for rye (and some ginger ale). This bears comparison with Prince Hal's comment on Falstaff's hotel bill.

In the main narrative dates are used sparingly but it is followed by a Chronology of the sequence of events. Thus the reader who is in a hurry, as most of us seem to be these days, can take in a lot of information in a little time.

A series of nearly one hundred brief biographies, with photographs, adds to our knowledge of the founders and of those who have served in the various offices of the organization - presidents, secretaries, treasurers, editors and managers. Also included are honorary members and recipients of the Canadian Forestry Achievement Award.

In the discusion of Forest Policy we are told that preparation of the CSFE Statement of 1943 involved active participation by a higher proportion of the total membership than any project undertaken before or since. One may wonder whether the strains and stresses of wartime stimulated this outburst of energy.

Difficulties of communication have always been a problem for Canadian foresters but posed a special handicap during the early years. Too few members were able to attend annual meetings and, for many, The Forestry Chronicle was the sole channel for keeping in touch. The problem was solved by the creation of local Sections, a movement which seems to have had its origin in the formation of a Forestry Club in Vancouver prior to 1915 . The book includes more or less lengthy notes about more than a score of Sections and their activities.

Other chapters deal with membership, awards, financial statements, the Chronicle and the numerous committees which have contributed so much to the Institute.

To this reviewer the story of the Institute seems typically Canadian. In the early forestry scene there was no single dominant leader, such as Gifford Pinchot in the United States; instead, a number of strong and able men - Fernow, Howe and Ellwood Wilson instantly come to mind but there were many others who worked together - and occasionally at cross purposes - to evolve the organization we now have. Progress from a founding membership of twelve to a figure well above two thousand bears witness to their success.

The story records much devotion to a good cause and at least as much self-criticism; it tells of great labours, long sustained, undertaken by some in the service of all; it shows that proceedings have almost always been democratic and that reaction was sharp on rare occasions when they were not. In the long run all concerned have been willing to accept the dictates of common sense.

Finally, a word of thanks to the author. Over a period of years he has undertaken a prodigious amount of work in assembling material and has brought it all to life in a style that sometimes sparkles and occasionally growls. And all this has been done as a "labour of love".

It has been said that he who undertakes the study of a community without knowledge of its history may observe much but understand little. With this book at hand there can be no excuse for superficial judgments as to the value of the Canadian Institute of Forestry. Mr. Fensom has put every member permanently in his debt. 